Abstracta Iranica Abstracta Iranica

Revue bibliographique pour le domaine irano-aryen

Volume 29 | 2008

Comptes rendus des publications de 2006

\title{
«Three inscribed Buddhist monastic utensils from Gandhāra ». ZDMG, 156, 2006, pp. 393-412.
}

\section{Frantz Grenet}

\section{(2) OpenEdition}

1 Journals

\section{Édition électronique}

URL : http://journals.openedition.org/abstractairanica/25322

DOI : 10.4000/abstractairanica.25322

ISSN : 1961-960X

Éditeur :

CNRS (UMR 7528 Mondes iraniens et indiens), Éditions de l'IFRI

\section{Édition imprimée}

Date de publication : 15 mai 2008

ISSN : 0240-8910

Référence électronique

Frantz Grenet, « «Three inscribed Buddhist monastic utensils from Gandhāra ». ZDMG, 156, 2006, pp. 393-412. », Abstracta Iranica [En ligne], Volume 29 | 2008, document 50, mis en ligne le 15 septembre 2008, consulté le 26 septembre 2020. URL : http://journals.openedition.org/abstractairanica/25322 ; DOI : https://doi.org/10.4000/abstractairanica.25322

Ce document a été généré automatiquement le 26 septembre 2020.

Tous droits réservés 


\title{
«Three inscribed Buddhist monastic utensils from Gandhāra ». ZDMG, 156, 2006, pp. 393-412.
}

\author{
Frantz Grenet
}

Parmi les objets (tous dans des collections privées) publiés ici, le premier (un plateau de bronze trouvé au Bunēr) a une importance toute particulière puisque l'inscription est datée de l'an 9 du souverain « indo-scythe » Azès, donc de son vivant, en 48 av. n.è., ce qui en fait la plus ancienne attestation de cette ère. Le dédicant est un mahākșatrapa local nommé Vasa-Abdagasès, fils de Mahāpāla-Suśpala, que son onomastique rattache d'une part à la dynastie de Vononès qui dans la région a précédé celle d'Azès (noms en śpala, forme est-iranienne de *spāda « armée " - le texte porte par erreur « ouestiranienne »), d'autre part à celle de l'« Indo-parthe " Gondopharès qui évince la dynastie d'Azès vers 20 de n.è. et domine toute la zone allant du Sistān au Gandhāra et au Sind. La structure politique pré-kouchane, au moins au Gandhāra, peut s'analyser comme une royauté multiple où l'on distingue trois échelons (mahäraja mahata, mahākșatrapa, kșatrapa), distribués entre plusieurs lignées selon une hiérarchie qui se recompose d'une période à l'autre. Dans un tel contexte la distinction entre "Indoscythes » et « Indo-parthes » n'a guère de sens. Malgré des affinités onomastiques avec la famille arsacide, le lien de Vononès, Gondopharès et leur clan avec la dynastie parthe demeure problématique. Il ne me parait pas non plus possible d'identifier, comme le voudrait l'A., Abdagasès neveu de Gondopharès avec le haut dignitaire homonyme que Tacite (Annales, VI, 37, 43-44) signale en Mésopotamie. 
INDEX

Thèmes : 3.1. Est de l'Iran

\section{AUTEURS}

FRANTZ GRENET

CNRS - EPHE - Paris 